\title{
KEPUASAN KERJA KARYAWAN PADA CV. MITRA BOGA TAMA
}

\author{
Yusnia Nasution \\ Psikologi, Fakultas Ilmu Pendidikan, Universitas Negeri Jakarta \\ Jakarta Timur \\ usninasti@gmail.com
}

\begin{abstract}
The purpose of this research is how the picture of the level of employee job satisfaction CV. Mitra Boga Tama in general are viewed from the six aspects of job satisfaction: the nature of work, attitude and superior leadership, the relationship between co-workers, working conditions, salaries and benefits, and opportunities to develop a career. It also determines which aspects of job satisfaction has been providing job satisfaction and aspects which do not provide job satisfaction.

This type of study is a descriptive quantitative questionnaires as primary data collection tool which is supported by interviews. The research was conducted on 26 respondents who are employees in the sample of the population CV. Mitra Boga Tama. Sample technique used is total sampling that is taking on the entire sample population, this is because the amount is less than 100 respondents. Prior to the analysis of data, it first tested the validity and reliability of research instruments with SPSS 17.0 for Windows. Validity testing is done using correlation Pearson Product Moment in SPSS program for windows version 17.00. As for the reliability of testing instruments in this study, reliability tests carried out using Cronbach Alpha Formula techniques and by using the SPSS program for windows 17.00.

The results showed that of the six aspects of job satisfaction: the nature of work, attitude and superior leadership, the relationship between co-workers, working conditions, salaries and benefits, and opportunities to develop a career, describing all aspects of employee job satisfaction. Moreover, if viewed a picture of the six aspects of job satisfaction that no aspect has been providing job satisfaction, four aspects of assessing only the neutral and the judge is not satisfied aspect is the aspect of salary and career development. From the results of this study can be in the know that the need for companies / leaders to improve the system or human resources personnel and employees need to do an evaluation for the purpose of the enterprise can be met or improved than before.
\end{abstract}

Key words: Job Satisfaction

\section{Pendahuluan}

Pekerjaan menghasilkan uang, kebebasan, dan kemandirian. Biasanya orang akan merasa puas atas kerja yang dijalankannya apabila apa yang dikerjakannya itu dianggap telah memenuhi harapannya sesuai dengan tujuannya bekerja. Apabila seseorang mendambakan sesuatu, itu berarti ia memiliki suatu harapan dan dengan demikian ia termotivasi untuk melakukan tindakan pencapaian harapan itu. Jika harapannya itu terpenuhi, ia akan merasa puas. Kepuasan kerja 
merupakan komponen dari sikap yang paling banyak diteliti. Hal ini disebabkan karena kepuasan kerja dapat meningkatkan motivasi kerja dan produktivitas kerja individu (Spector,2000:1996).

Kepuasan kerja adalah pandangan positif karyawan terhadap pekerjaannya, lingkungannya, relasi kerjanya, dan lain sebagainya yang berhubungan dengan pekerjaannya. Menurut Robbins "Kepuasan kerja adalah sebagai suatu sikap umum seorang individu terhadap pekerjaannya, pekerjaan menuntut interaksi dengan rekan kerja, atasan, peraturan dan kebijakan organisasi, standar kinerja, kondisi kerja dan sebagainya. Seorang dengan tingkat kepuasan kerja tinggi menunjukkan sikap positif terhadap kerja itu, sebaliknya seseorang tidak puas dengan pekerjaannya menunjukkan sikap negatif terhadap kerja itu. (Robbins, 1996 : 179).

Menurut Herzberg seperti yang dikutip oleh Suryana Sumantri (2001:83), ciri perilaku pekerja yang puas adalah mereka yang mempunyai motivasi yang tinggi untuk bekerja, mereka lebih senang dalam melakukan pekerjaannya, sedangkan ciri pekerja yang kurang puas adalah mereka yang malas berangkat bekerja ketempat bekerjanya dan malas dalam melakukan pekerjaannya. Sehingga dapat disimpulkan bahwa kepuasan kerja adalah perasaan atau sikap seseorang terhadap pekerjaan yang dilakukanya, yang dapat dipengaruhi oleh berbagai macam faktor, baik itu faktor internal maupun faktor eksternal, dan faktor-faktor tersebut yang akan menentukan mengapa karyawan merasa puas atau tidak puas dalam menjalankan pekerjaanya.

Menurut Job Descriptive Index (JDI) faktor penyebab kepuasan kerja adalah :

1. Bekerja pada tempat yang tepat

2. Pembayaran yang sesuai

3. Organisasi dan manajemen

4. Supervisi pada pekerjaan yang tepat

5. Orang yang berada dalam pekerjaan yang tepat

Sedangkan menurut Hasibuan (2005:203)

kepuasan kerja karyawan dipengaruhi oleh faktorfaktor :

1. Balas jasa yang layak dan adil

2. Penempatan yang tepat dan sesuai dengan keahlian

3. Berat ringannya pekerjaan

4. Suasana dan lingkungan pekerjaan

5. Peralatan yang menunjang pelaksanaan pekerjaan

6. Sikap pemimpin dalam kepemimpinannya

7. Sifat pekerjaan monoton atau tidak

Perusahaan keluarga adalah sebuah perusahaan yang dimiliki, dikontrol, dan dijalankan oleh anggota sebuah atau beberapa keluarga. Meskipun demikian, bukan berarti bahwa semua pekerja dalam perusahaan harus merupakan anggota keluarga. Banyak perusahaan keluarga, terutama perusahaan-perusahaan kecil, memperkerjakan orang lain untuk menempati posisi rendahan, sementara posisi tinggi (top manager) dipegang oleh orang dari dalam keluarga pemilik perusahaan.

CV Mitra Boga Tama merupakan perusahaan yang bersifat kekeluargaan dan merupakan perusahaan keluarga, sehingga segala keputusan tergantung dari pemiliki modal atau sekutu pasif. Begitu juga dalam pengambilan keputusan mengenai masalah karyawan. Pelaksanaan analisa jabatan berpatokan pada satu pihak yaitu HRD dimana pada perusahaan ini hanya satu orang yang melaksanakannya. Pihak HRD merekrut calon karyawan tergantung pada laporan dari masing-masing manager yang membutuhkan tenaga. Tenaga yang di butuhkan dapat dilihat dari kebutuhan produksi, supplier, dan logistik. Jika terjadi kenaikan pada ketiga kegiatan tersebut maka masing-masing manager melaporkan kepada pihak HRD untuk melakukan perekrutan karyawan. Setelah itu HRD membuat dan menyebar brosur atau lowongan pekerjaan. Jadi perusahaan ini menarik karyawan hanya dengan melalui satu orang yang bukan dibidangnya, sehingga perputaran atau turnover karyawan kurang mendapat perhatian. Selain itu perputaran karyawan dilihat karena adanya peningkatan produksi pada masing-masing bagian bukan karena faktor lain atau faktor dari karyawan itu sendiri. Jika tidak terjadi kenaikan produksi maka tidak melakukan perekrutan karyawan. Perusahaan akan tetap mempertahankan karyawan yang ada agar biaya produksi tetap stabil. Sebaliknya jika perusahaan itu mengalami penurunan produksi maka akan dilakukan pengurangan karyawan.

Pada CV Mitra Boga Tama sebelumnya tidak pernah melakukan penelitian atau pun evaluasi mengenai kepuasan kerja karyawan, sehingga tidak ada gambaran bagaimana kepuasan kerja para karyawan pada perusahaan tersebut. Oleh karena itu fokus peneltian ini yaitu menggambarkan tentang enam aspek kepuasan kerja karyawan pada CV Mitra Boga Tama yaitu sifat pekerjaan itu sendiri, kepemimpinan, hubungan antar rekan kerja, kondisi kerja, gaji , dan kesempatan mengembangkan karir.

\section{Metode Penelitian}

2.1 Tipe Penelitian 
Dalam penelitian ini, jenis penelitian deskripstif kuantitatif bertujuan untuk mengetahui gambaran tingkat kepuasan kerja seluruh karyawan $\mathrm{CV}$ Mitra Boga Tama tidak termasuk pemilik perusahaan dan direktur. Penelitian ini juga termasuk penelitian studi kasus, yaitu penelitian tentang subjek penelitian yang berkenaan dengan suatu fase spesifik/khas dari keseluruhan personalitas (Maxfield dalam Natsir 1998).

\subsection{Populasi dan Sample}

Jumlah populasi dalam penelitian ini sebesar 28 orang, maka teknik penarikan sample yang dipilih adalah total sampling. Total sampling merupakan teknik penentuan sample yang mengambil seluruh anggota populasi sebagai sample penelitian (Sugiono 2003,91). Dengan total sampling diharapkan tingkat keakuratan yang diperoleh dari hasil penelitian ini akan relatif lebih tinggi.

2.3 Teknik Pengumpulan Data

Dalam penelitian ini menggunakan instrument yang telah ada dan tidak melakukan modifikasi dan translation pada instrument tersebut. Adapun instrument ini di peroleh dari penelitian skripsi S1 oleh Eka Jumarlita jurusan kepustakaan Universitas Indonesia yang berjudul "Kepuasan Kerja Staff Perpustakaan : Studi Kasus Di Lingkungan Universitas Indinesia". Instrumen dalam skripsi ini didasarkan pada The Job Satisification Survey (JSS; Spector,1985) dan digunakan untuk mengukur kepuasan kerja staff perpustakaan Universitas Indonesia dari keenam aspek kepuasan kerja. Adapun populasi dan sample penelitian itu seluruh staff perpustakaan Universitas Indonesia. Instrument itu terdiri dari 30 aitem dan validitas dan reabilitasnya cukup tinggi.

Dalam penelitian ini proses pengumpulan data dilakukan melalui :

1. Studi Literatur

Studi literatur dilakukan dalam upaya untuk menggali konsep dan memahami teori-teori dari literature serta dokumen yang berkaitan dengan masalah penelitian.
2. Kuesioner atau Instrumen penelitian

Kegiatan pengumpulan data yang utama dalam penelitian ini adalah penyebaran kuesioner. Kuesioner merupakan rangkaian pertanyaan tentang suatu hal atau sutau bidang yang digunakan untuk memperoleh data berupa jawaban-jawaban dari para responden (Koentjaraningrat 1993,173). Isi pertanyaan dalam kuesioner ini dapat berupa pertanyaan tentang fakta dan pendapat dalam bentuk pertanyaan terbuka dan tertutup. Hasil kuesioner tersebut akan diolah menjadi angka-angka, table-tabel, analisa statistic, dan pembahasan serta penarikan kesimpulan hasil penelitian. Analisa data kuantitatif dilandaskan pada hasil kuesioner tersebut (Singarimbun 1989,175).

Bentuk pertanyaan untuk kuesioner dalam penelitian ini adalah pertanyaan tertutup, yaitu pertanyaan yang dilengkapi dengan alternatif jawaban sehingga responden hanya tinggal memilih salah satu jawaban yang sesuai dengan kenyataan dan yang dirasakan oleh responden yang bersangkutan. Pada bagian akhir dari kuesioner, responden diminta untuk memberikan saran dan harapannya menyangkut masalah kepuasan kerja yang dialami responden, hal ini berguna sebagai data pendukung dalam melakukan analisis data.

Adapun skala kepuasan kerja berdasarkan teori dua faktor Herzberg baik secara intrinsik maupun ekstrinsik maka ada enam aspek kepuasan kerja yaitu sifat pekerjaan, sikap dan kepemimpinan atasan, hubungan antar rekan kerja, kondisi kerja, gaji dan tunjangan, dan kesempatan mengembangkan karir.

Dalam penelitian ini, jawaban responden untuk bagian pertanyaan mengenai kepuasan kerja diungkapkan dengan menggunakan skala Likert. Skala Likert adalah pertanyaan sikap seseorang terhadap sesuatu yang diukur dengan 5 poin tingkat 
kepuasan. Berikut penjelasan dari skala Likert yang akan digunakan dalam kuesioner :

5 poin : Sangat Puas, bila pada kenyataan yang dirasakan saat ini melebihi harapannya.

4 poin : Puas, bila kenyataan yang dirasakan saat ini sesuai dengan kebutuhan.

3 poin : Netral, bila tidak dapat memutuskan jawaban setuju atau tidak.

2 poin : Tidak Puas, bila kenyataan yang dirasakan tidak sesuai dengan kebutuhan

1 poin : Sangat Tidak Puas, bila kenyataan yang dirasakan saat ini sangat tidak sesuai dengan kebutuhan.

Pertanyaan-pertanyaan dalam kuesioner dibagi menjadi 2 bagian. Pada bagian pertama berisi pertanyaan tentang data dasar responden yang meliputi jenis kelamin, tingkat pendidikan, dan jabatan. Sedangkan pada bagian kedua adalah beberapa indikator pengukuran kepuasan kerja antara lain : aspek sifat pekerjaan yang dibebankan kepada karyawan, kepemimpinan atasan, hubungan antarrekan kerja, kondisi kerja (lingkungan fisik), gaji/tunjangan dan kesempatan mengembangkan karir. Masing-masing aspek kepuasan kerja tersebut akan diukur dengan menggunakan beberapa pertanyaan.

3. Wawancara

Pengumpulan data dalam penelitian ini juga didukung dengan mewawancarai direktur dan manajer perusahaan $\mathrm{CV}$ Mitra Boga Tama untuk memperoleh informasi tantang karyawan serta kebijakan pengelolaan sumber daya manusia di perusahaan tersebut.

\subsection{Pengolahan Data}

Kuesioner yang telah terkumpul akan diolah secara kuantitatif, dimulai dengan memberikan skor untuk setiap pertanyaan dalam kuesioner dari setiap responden. Pemberian skor ini untuk mengukur pendapat responden tentang objek penelitian yaitu kepuasan kerja karyawan dengan menggunakan skala Likert. Selanjutknya data yang telah diolah disajikan dalam bentuk tabel dan grafik untuk kemudian dianalisis secara kuantitatif. Berikut tahap pengolahan data dalam penelitian ini

1. Penyuntingan

Penulis akan memeriksa apakah seluruh data dari kuesioner yang telah dikembalikan responden memenuhi syarat untuk diolah artinya apakah semua pertanyaan dalam kuesioner tersebut telah diisi lengkap, jika tidak lengkap kuesioner tersebut dinyatakan tidak valid dan tidak dapat diolah.

2. Penilaian (skoring) dan input data Dalam menjawab suatu pertanyaan tentang kepuasan kerja seringkali menjadi hal yang tidak mudah bagi responden untuk mengungkapkan tingkat kepuasan yang dirasakan. Untuk itu digunakan skala Likert karena skala ini memiliki gradasi jawaban mulai dari yang sangat positif sampai dengan yang sangat negatif, sehingga responden dapat dengan mudah menentukan pilihan jawaban yang sesuai dengan apa yang dirasakan.

Pada tahap ini penulis memberikan nilai (skor) terhadap jawaban pada tiap pertanyaan yang terdapat dalam kuesioner. Setiap jawaban diberikan nilai sebagai berikut :

Tabel 3.6

Nilai Skor

\begin{tabular}{cc}
\hline $\begin{array}{c}\text { Pertanyaan } \\
\text { Kepuasan }\end{array}$ & Nilai \\
\hline Sangat Puas (SP) & 5 \\
Puas (P) & 4 \\
Netral (N) & 3 \\
Tidak Puas (TP) & 2 \\
Sangat Tidak Puas & 1 \\
(STP) & \\
\hline
\end{tabular}

Data yang diperoleh dari setiap jawaban, kemudian diolah dengan bantuan Statistical Program For The Social Sciences (SPSS) 17.0 version for Windows.

3. Perhitungan Frekuensi dan Presentase

Penulis menghitung semua data yang dihasilkan dari responden dengan 
bantuan SPSS. Program ini memudahkan penulis untuk perhitungan data statistik dalam proses pengolahan data dan menyajikan hasilnya.

Agar memudahkan penafsiran terhadap nilai persentase data yang telah diolah, maka akan digunakan ukuran penafsiran menurut Wasito $(1992,10)$ sebagai berikut :

$0 \% \quad$ : Tidak satupun

$1 \%-25 \%$ : Sebagian kecil

$26 \%$ - $49 \%$ : Hampir setengahnya

$50 \% \quad$ : Setengahnya

$51 \%-75 \%$ : Sebagian besar

$76 \%$ - $99 \%$ : Hampir seluruhnya

$100 \%$ : Seluruhnya

Data yang akan diperoleh dari hasil pengolahan data adalah berupa angkangka seperti sebaran frekuensi dan presentase. Dalam proses analisa hasil penelitian, penafsiran nilai-nilai presentase di atas dapat memudahkan penulis untuk menyatakan ke dalam kalimat-kalimat pernyataan yang lebih jelas.

2.5 Analisis Data

Data yang telah dihitung kemudian dikelompokkan dan disusun ke dalam aspek-aspek kepuasan kerja yang telah ditentukan. Setelah itu adalah proses tabulasi, yaitu data yang telah tersusun dimasukan dalam bentuk tabel dan grafik, karena proses tabulasi ini merupakan langkah awal dari analisa data deskriptif. Data yang terdapat dalam tabel dan grafik tersebut dipaparkan secara deskriptif kedalam kalimat-kalimat pernyataan yang menggambarkan secara jelas keadaan atau kondisi kepuasan kerja karyawan CV. Mitra Boga Tama. Dari hasil analisis tersebut akan diambil beberapa kesimpulan yang pada akhirnya dapat menjawab pertanyaan penelitian sehingga tujuan dari penelitian ini juga akan tercapai

\section{Hasil dan Diskusi}

Berikut ini merupakan pembahasan dari data yang telah didapat tentang tingkat kepuasan kerja karyawan CV. Mitra Boga Tama. Dalam sub bab ini akan menggambarkan penilaian karyawan CV. Mita Boga Tama terhadap ke-6 aspek kepuasan kerja yaitu sifat pekerjaan, sikap dan kepemimpinan atasan, hubungan antar rekan kerja, kondisi kerja (Lingkungan fisik), gaji dan tunjangan, serta kesempatan mengembangkan karir. Untuk penelusuran tingkat kepuasan kerja pada masing-masing aspeknya, dapat terlihat seperti di bawah ini :

1. Pernyataan Terhadap Aspek Sifat Pekerjaan

Grafik 4.1

Grafik Bar Kepuasan Kerja pada Aspek Sifat Pekerjaan

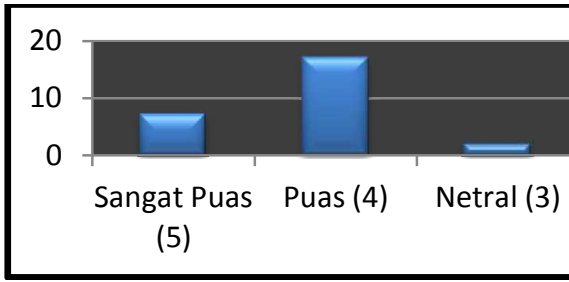

Dari data diatas menunjukkan bahwa sebanyak 17 orang $(65.4 \%)$ atau sebagian besar karyawan CV. Mitra Boga Tama menilai pekerjaan mereka memuaskan dan 7 orang $(26.9 \%)$ menilai sangat memuaskan, sementara itu ada 2 orang (7.7\%) yang menjawab netral. Hasil ini cukup mengejutkan bahwa dari hasil survei ternyata tidak ada satupun karyawan CV.Mitra Boga Tama yang menilai pekerjaan mereka tidak memuaskan dan sangat tidak memuaskan. Dengan demikian dapat disimpulkan bahwa sebagian besar karyawan CV.Mitra Boga Tama telah merasa puas terhadap pekerjaan yang mereka lakukan.

Hal ini tentu sangat mempengaruhi peningkatan kinerja dan produktifitas mereka dalam bekerja, seperti yang dikemukakan oleh Cook dan Hunsaker $(2001,24)$ yang mengatakan bahwa pegawai yang senang adalah pegawai yang produktif dan inovatif.

2. Pernyataan Terhadap Aspek Sikap dan Kepemimpinan Atasan

Grafik 4.2

Grafik Bar Kepuasan kerja pada Aspek Sikap dan Kepemimpinan Atasan 


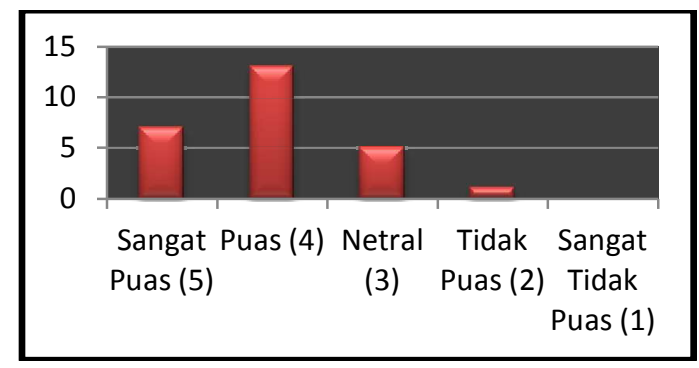

Dari data diatas menunjukkan bahwa sebanyak 13 orang $(50 \%)$ karyawan CV. Mitra Boga Tama menilai kepemimpinan atasan mereka memuaskan, hanya 7 (26.9\%) orang yang menilai sangat memuaskan, sedangkan 5 orang (19.2\%) menjawab netral dan 1 orang $(3.8 \%)$ yang menilai tidak memuaskan, sedangkan tidak ada yang menilai sangat tidak memuaskan.

Penilaian seperti ini merupakan hal yang subjektif, akan tetapi tidak ada satupun yang menilai dengan ekstrim bahwa atasan mereka sangat tidak memuaskan. Dengan demikian dapat disimpulkan bahwa sebagian karyawan CV.Mitra Boga Tama menilai kepemimpinan atasan mereka memuaskan. Hasil penelitian ini dapat menunjukkan bahwa kepemimpinan atasan para karyawan CV. Mitra Boga Tama telah dikatakan baik dan mengerti bagaimana cara memperlakukan karyawan sebagaimana mestinya sesuai dengan kemampuan dan kontribusi mereka terhadap perusahaan, sehingga karyawan pun merasa diakui dan dihargai atas apa yang telah mereka lakukan untuk perusahaan.

3. Pernyataan Terhadap Aspek Hubungan Antar Rekan Kerja

Grafik 4.3

Grafik Bar Kepuasan kerja pada Aspek Hubungan antar Rekan Kerja

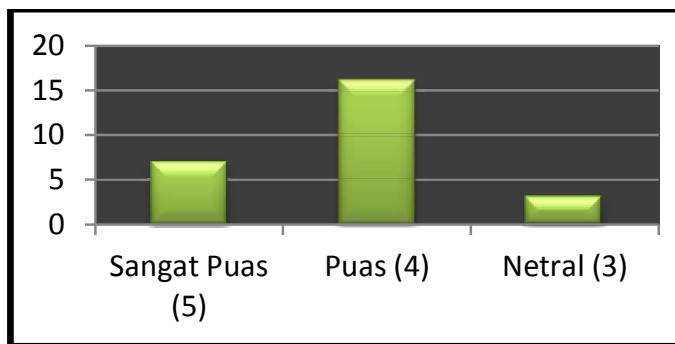

Dari data diatas menunjukkan bahwa sebanyak 16 orang $(61.5 \%)$ menilai hubungan antar rekan kerja memuaskan, 7 orang $(26.9 \%)$ menilai sangat memuaskan, 3 orang (11.5\%) tidak dapat memutuskan jawaban.

Penelitian seperti ini merupakan suatu hal yang biasa jika dalam suatu organisasi seperti perusahaan terjadi ketidakcocokan satu sama lain, karena setiap orang begitupun juga para karyawan $\mathrm{CV}$ Mitra Boga Tama memiliki banyak perbedaan, baik perbedaan karakter maupun perbedaan kepentingan.

Berdasarkan data diatas

maka dapat disimpulkan bahwa sebagian besar karyawan $\mathrm{CV}$. Mitra Boga Tama menilai bahwa hubungan antar rekan kerja adalah memuaskan. Kondisi seperti ini tentu saja akan mendukung bagi peningkatan kepuasan kerja karyawan CV. Mitra Boga Tama. Hubungan dengan sesama rekan kerja yang cenderung baik, dapat menimbulkan suasana kerjasama yang sehat dan menyenangkan.

4. Pernyataan Terhadap Aspek Kondisi Kerja

Grafik 4.4

Grafik Bar Kepuasan Kerja pada Aspek Kondisi Kerja

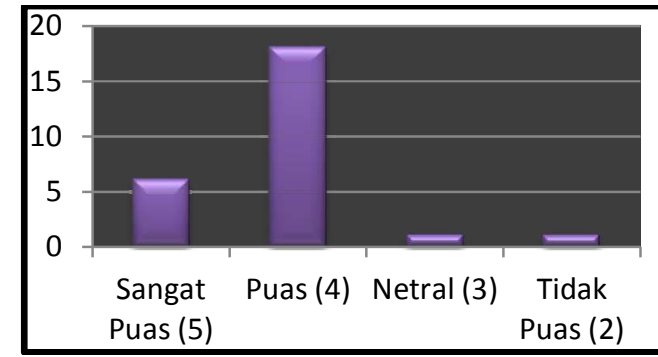

Data

diatas

menunjukkan bahwa sebanyak 18 orang $(69.2 \%)$ menilai kondisi kerja tempat mereka bekerja memuaskan, 
selain itu ada 6 orang (23.1\%) yang menilai sangat memuaskan, ada 1 orang $(3.8 \%)$ menilai netral. Sementara itu ada 1 orang $(3.8 \%)$ yang menilai kondisi kerja tidak memuaskan.

Dengan demikian dapat disimpulkan bahwa sebagian besar karyawan CV.Mitra Boga Tama telah merasa puas terhadap kondisi kerja. Hal ini dapat memberikan informasi kepada perusahaan bahwa tempat bekerja karyawan telah memberikan rasa tenang dan nyaman dan bagi karyawan yang merasa kondisi kerja kurang baik perusahaan dapat memperbaiki bagian apa pada tempat kerja yang membuat karyawan merasa kurang baik.

5. Pernyataan Terhadap Aspek Gaji dan Tunjangan

Grafik 4.5

Grafik Bar Kepuasan Kerja pada Aspek Gaji dan Tunjangan

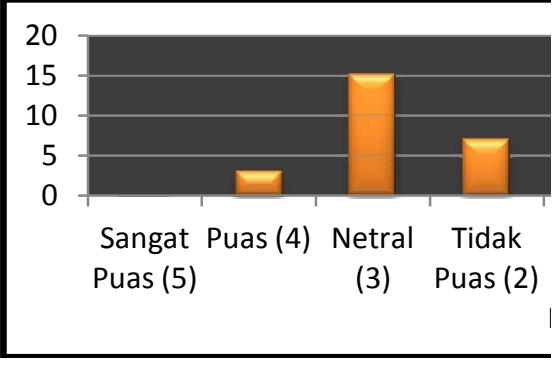

Berbeda dengan aspek kepuasan kerja lainnya, data yang diperoleh untuk aspek gaji dan tunjangan sangat ekstrim, terlihat bahwa tidak ada karyawan yang menilai gaji dan tunjangan sangat memuaskan, hanya ada 3 orang $(11.5 \%)$ yang menilai memuaskan, sebanyak 15 orang $(57.7 \%)$ tidak dapat memberikan jawaban. Sementara itu yang cukup mengejutkan bahwa ada karyawan yang menilai gaji dan tunjangan kurang, yaitu ada 7 orang (26.9\%) yang menilai tidak memuaskan dan 1 orang $(3.8 \%)$ yang menilai sangat tidak memuaskan.

Dengan demikian dapat disimpulkan bahwa sebagian besar karyawan tlebih bersikap netral menilai gaji dan tunjangan yang diterima. Data diatas memberikan informasi kepada kita bahwa penilaian karyawan CV Mitra Boga Tama terhadap aspek gaji dan tunjangan adalah cukup mengejutkan. Artinya bahwa karyawan menilai tidak puas terhadap gaji dan tunjngan tetapi ada pula yang menjawab puas, sebagian besar dari karyawan tidak mampu memberikan jawaban. Perbedaan ini tentu dipengaruhi oleh banyak faktor seperti perbedaaan tingkat pendidikan, jabatan, pengalaman, keahlian, bahkan gaya hidup.

$$
\text { Penulis berpendapat }
$$

bahwa pemberian gaji dan tunjangan kepada karyawan kurang baik, karena berdasarkan data yang telah didapat penilaian yang paling banyak adalah netral, sedangkan tidak ada penilaian sangat memuaskan dan hanya ada memuaskan yang nilainya lebih sedikit dari tidak memuaskan. Oleh karena itu pihak perusahaan harus lebih memperhatikan kebutuhan karyawan terutama pemberian gaji dan perlu untuk terus memperbaiki dan meningkatkan sistem gaji dan tunjangan yang diberikan karena cukup banyak karyawan yang merasa kecewa karena gaji yang mereka terima.

6. Pernyataan Terhadap Aspek Kesempatan Mengembangkan Karir

Grafik 4.6

Grafik Bar Kepuasan Kerja pada Aspek Kesempatan Mengembangkan Karir

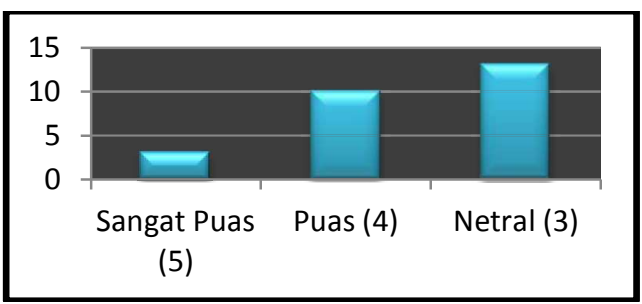

Data diatas menunjukkan bahwa sebanyak 10 orang $(38.5 \%)$ menilai kesempatan mengembangkan karir adalah memuaskan, 3 orang (11.5\%) menilai sangat memuaskan. Sementara itu sebanyak 13 orang (50\%) tidak dapat memutuskan jawaban atau memilih untuk bersikap netral dan tidak ada yang menilai tidak memuaskan serta tidak ada 
satupun dari para karyawan yang menyatakan sangat tidak puas.

$$
\text { Cukup banyak yang }
$$

memilih untuk bersikap netral dalam kuesioner ini disebabkan karena para karyawan merasa pelatihan yang diberikan tidak sesuai dengan harapan mereka dan kebutuhan kerja saat ini. Dapat disimpulkan bahwa sebagian besar karyawan $\mathrm{CV}$. Mitra Boga Tama tidak dapat memutuskan penilaian atau bersikap netral terhadap penilaian aspek kesempatan mengembangkan karir. Dari data ini memberikan informasi kepada kita khususnya bagi perusahaan harus memberikan pelatihan dan pendidikan formal maupun non formal dan terus ditingkatkan agar para karyawan CV. Mitra Boga Tama semakin terlatih dan profesionel dalam melakukan pekerjaannya sehingga dapat memberikan hasil yang maksimal dalam pencapaian tujuan perusahaan.

7. Pernyataan Tingkat Kepuasan Kerja secara Keseluruhan

Setelah membahas tingkat kepuasan kerja dilihat dari masingmasing aspek di atas, maka pada bagian ini akan diketahui tingkat kepuasan kerja karyawan CV Mitra Boga Tama secara keseluruhan, hasilnya sebagai berikut :

Grafik 4.7

Grafik Bar Tingkat Kepuasan Kerja secara Keseluruhan

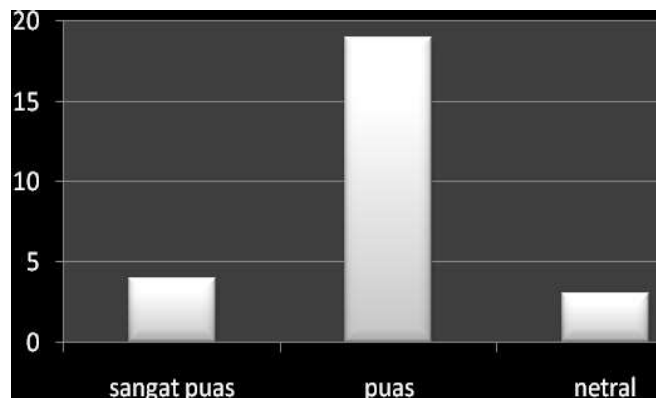

Dari data diatas menunjukkan bahwa penilaian dari seluruh karyawan terhadap seluruh aspek kepuasan kerja, sebanyak 19 orang (73.1\%) menilai memuaskan, 4 orang (15.4\%) menilai sangat memuaskan, 3 orang $(11.5 \%)$ menilai netral, dan tidak ada karyawan yang menilai tidak puas dan sangat tidak memuaskan. Data ini terlihat cukup mengejutkan bahwa tidak ada satupun karyawan yang menilai tidak puas dan sangat tidak puas dan dapat disimpulkan bahwa sebagian karyawan CV Mitra Boga Tama menilai secara keseluruhan aspek kepuasan kerja adalah puas.

\section{Kesimpulan}

Berdasarkan hasil analisis penelitian maka dapat disimpulkan bahwa :

a. Semua aspek kepuasan kerja menggambarkan kepuasan kerja karyawan

b. Berdasarkan rata-rata setiap aspek kepuaan kerja maka ada empat aspek yang memberikan jawaban netral, sedangkan yang belum memberikan kepuasan kerja yaitu gaji atau tunjangan dan kesempatan mengembangkan karir

\section{Daftar Pustaka}

Arikunto, Siharsimi. (2000). Prosedur Penulisan : suatu pendekatan prakte. Edisi revisi. Jakarta : Renika Cipta.

Armeini R, Anna. (2010). Analisis Data Penelitian Kuantitatif Dengan SPSS. Jakarta.

Azwar, Saifudin. (2008). Penyusunan Skala Psikologi. Yogyakarta : Pustaka pelajar.

Cooper, Cory. (2005) "Research reveals that dissatisfication at work causes illness". http://www.lums.lances.ac.uk/news/cooper research/.

Davis, Keith dan John W. Newstrom. (1995). Perilaku organisasi. Edisi ke-7. Jakarta : Erlangga.

Hasibuan, Melayu SP. (2001). Manajemen SDM, Edisi revisi. Bumi aksara

Hartono. (2004). Manajemen SDM. Edisi revisi. Bumi aksara.

Jumarlita Eka. (2008). Kepuasan Kerja Staf Perpustakaan : Studi Kasus Dilingkungan Universitas Indonesia. 
Keit, Davis, Jhon W, New strom. (1995). Perilaku dalam Organisasi, Edisi ke-7. Jakarta: Erlangga

Koentjaraningrat. (1993). Metode-metode penelitian masyarakat. Edisi ke-3. Jakarta : Gramedia.

Muhaimin. "Hubungan antara kepuasan kerja dengan disiplin kerja karyawan operator shawing computer bagian produksi pada PT. Primarindo Asia International,Tbk. di Bandung". (2004). Palembang : Fakultas psikologi Universitas Bina Dharma Palembang.

http://psikologi.binadarma.ac.id/jurnal/jur nalmuhaimin.pdf.

Munandar, Ashar Sunyoto. (2001) . Psikologi Industri dan organisasi. Jakarta : UI press.

Moch As'ad. (1995). Psikologi Industri. Jakarta : Liberty

Robbins Stephans. (1994). Organizational Theory, Structur, Design, and Aplication, Alih bahasa Yusuf Udara, Arean. Jakarta.

Roussel. "Motivation and Productivity Related to Job Satisfication". 1999

http://www.causework.ifo/i/12520.html.

Singarimbun, Masri dan Sofyan Effendi. (1989). Metode Penelitian Survei. Edisi revisi. Jakarta : LP3ES.

Sudijono Anas. (2008). Pengantar Statistik Pendidikan. Jakarta : PT. Raja Garfindo.

Sugiono. (2003). Metode Penelitian Administrasi. Jakarta : C.V Alfabeta.
Sugiono. (2009). Metode Penelitian Kuantitatif Kualitatif dan R\&D. Bandung : C.V Alfabeta.

Winardi. (2000). Asas-asas Manajemen. Bandung : Mandar Maju.

Winardi. (2004). Manajemen Perilaku Organisasi. Jakarta : Prenada Media.

Wursanto. (2003). Dasar-dasar Ilmu Organisasi. Yogyakarta : Penerbit Andi. 